IIIIIIIIIIIIIIIIIIIIIIIIIII

$$
\text { ミニレビュー }
$$

|IIIIIIIIIIIIIIIIIIIIIIIIIII

\title{
農薬はどう教えられているが
}

\author{
宮川恒*
}

京都大学農学研究科

（2016年11月20日受理）

\section{How do people know what pesticides are?}

\author{
Hisashi Miyagawa \\ Graduate School of Agriculture, Kyoto University, Kyoto 606-8502, Japan
}

Keywords: education, Wikipedia, risk communication.

\section{1.は じめに}

大学で農薬のことを授業で教える際に, 学生に対して 「知っている農薬の名前を挙げてください」というアンケー トをおこなうことがしばしばある。ほとんどの学生の回答 は「名前を知っている農薬はありません」である。たいてい の場合, 学生は農薬に対してネガティブなイメージを持って いる（ただし最近は，別になんとも思わない（興味ない）と いうものも少なからずいる). 個々の農薬は知らないけれど, とにかく「集合名詞」としての農薬に悪いイメージをもって いるということのようだ.

一方で，少数ながら必ず名前が出てくるのがDDTであ る. ダイオキシンというのもよく出てきて驚かされる．最近 ではグリホセートも散見される．ラウンドアップが遺伝子組 換えとの関連で紹介されるためとみられる．なぜこうなるの か興味を持ったので，今，農薬はどのように教えられている のかについて調べてみた.

\footnotetext{
\#第41回大会シンポジウムを取りまとめた解説.

* 干 606-8502 京都市左京区北白川追分町

E-mail: miyagawa@kais.kyoto-u.ac.jp

(c) 日本農薬学会
}

\section{2. 学習指導要領に見る農薬}

文部科学省が示している学習指導要領で, 内容に農薬が関 連すると思われる部分を表 1 によめた。「農薬」という単語 自体は，小学校から高校（普通科）まで出てこない。農業科 の教科「作物」「野菜」などでは生産における栽培管理の中 で「ポジティブリスト制度」が出てくるが，まずは農薬の役 割を理解させるという記述がほしいところだ。

直接「農薬」とは書かれていないが，農薬の話が出てきそ うなのが小学校の社会 5 年である. 高校の化学でも日常生活 や社会を支える化学物質として農薬が取り上げられておかし くない. 高校の家庭科では, 食事と健康に関連して農薬に触 れる機会がありそうだ.

続いて実際に教科書の中で，どのように「農薬」が登場す るのか見てみよう。

\section{3. 教科書に見る農薬}

\section{1. 小学社会 5 年}

ここでは「私たちの食生活と食料生産」を学ぶために，ま ず米作りのさかんな地域を取り上げ, 小学生が調べる形を とって実際にどのようなことがおこなわれ問題になってい るのかが紹介される. 参照した日本文教出版の平成 27 年度 版 ${ }^{3)}$ では山形県庄内平野の地理的な条件が解説された後, 
表 1. 学習指導要領に見る農薬と関連した記述 ${ }^{1,2}$ )

\begin{tabular}{|c|c|c|}
\hline 教科 & 科目 & 内容 \\
\hline $\begin{array}{l}\text { 小学校 } \\
\text { 社会 }\end{array}$ & 第5学年 & $\begin{array}{l}\text { (2) 我が国の農業や水産業について, 次のことを調査したり } \\
\text { 地図や地球儀, 資料などを活用したりして調べ, それらは国 } \\
\text { 民の食料を確保する重要な役割を果たしているとや自然環 } \\
\text { 境と深いかかわりをもって営まれていることを考えるように } \\
\text { する. } \\
\text { ア 様々な食料生産が国民の食生活を支えていること, 食 } \\
\text { 料の中には外国から輸入しているものがあること. } \\
\text { イ 我が国の主な食料生産物の分布や土地利用の特色など } \\
\text { ウ 食料生産に従事している人々の工夫や努力, 生産地と } \\
\text { 消費地を結ぶ運輸などの働き }\end{array}$ \\
\hline $\begin{array}{l}\text { 高校 } \\
\quad \text { 理科 }\end{array}$ & 化学基礎 & $\begin{array}{l}\text { (1) 化学と人間生活 } \\
\text { 化学と人間生活とのかかわりについて関心を高め, 化学が物質 } \\
\text { を対象とする科学であることや化学か人間生活に果たしている } \\
\text { 役割を理解させるとともに, 観察, 実験などを通して物質を探 } \\
\text { 究する方法の基礎を身につけさせる. } \\
\text { ア 化学と人間生活とのかかわり } \\
\text { (ア) 人間生活の中の化学 } \\
\text { 日常生活や社会を支える物質の利用とその製造の例 } \\
\text { を通して, 化学に対する興味・関心を高めること. } \\
\text { (イ）化学とその役割 } \\
\text { 日常生活や社会において物質が適切に使用されて } \\
\text { いる例を通して, 化学が果たしている役割を理解 } \\
\text { すること. }\end{array}$ \\
\hline
\end{tabular}
（4）有機化合物の性質と利用

有機化合物の性質や反応を観察, 実験などを通して探究し, 有 機化合物の分類と特徵を理解させるとともに，それらを日常生 活や社会と関連づけて考察できるようにする.

亿 有機化合物と人間生活

（ア）有機化合物と人間生活 有機化合物が，その特徴を活かして人間生活の中 で利用されていることを理解すること。

家庭 家庭基礎

（2）生活の自立及び消費と環境

ア 食事と健康

健康で安全な食生活を営むために必要な栄養, 食品, 調理及び食品衛生などの基礎的・基本的な知識と技術 を習得させ，生涯を見通した食生活を営むことができ るようにする。

オ ライフスタイルと環境 生活と環境とのかかわりについて理解させ，持続可能 な社会を目指してライフスタイルを工夫し，主体的に 行動できるようにする。

家庭総合（4）生活の科学と環境

ア食生活の科学と文化

栄養, 食品, 調理及び食品衛生などについて科学的に 理解させ，食生活の文化に関心をもたせるとともに， 必要な知識と技術を習得して安全と環境に配慮し, 主 体的に食生活を営むことができるようにする。

農業＼cjkstart農業と環境（2）農業生産の基礎

亿 農業生物の栽培・飼育

作物 （3）作物の生産

野菜（3）野菜の生産

食品化学 （5）食品の衛生検査

力 農薬と食品

アの（ア）については，代表的な金属やプラスチックを报う

こと，その際，再利用にも触れること．

（イ）については, 洗剤や食品添加物など身近な例を扱うこ と. その際, 物質の性質や使用する量が有効性と危険性に関 連していることにも触れること。

イの（ア）については，アで取り上げた物質のほか，単糖類， 二糖類，アミノ酸などを扱うこと。また，代表的な医薬品， 染料，洗剤などの主な成分にも触れること。

オについては, 環境負荷の少ない衣食住の生活の工夫に重点 を置くこと.

内容の（2）については, 農業生物の育成に関するプロジェク 卜学習を通して, 農業生物の育成と栽培・飼育環境を関連づけ て理解させるとともに, 科学的な見方と実践力を育てること. 内容の（3）については, 品種の選定をはじめとする栽培計 画, 各生育段階の特性に応じた栽培管理, 各生育段階の診断 方法に基づく評価など作物の生産と経営について体系的に报 うこと。また，残留農薬のポジティブリスト制度の概要につ いても触れること。

内容の（3）については, 野菜の作型の選定をはじめとする栽 培計画, 各生育段階の特性に応じた栽培管理, 各生育段階の 診断方法に基づく評価など野菜の生産と経営について体系的 に扱うこと。 また, 残留農薬のポジティブリスト制度の概要 についても触れること.

内容の（5）のカについては, 残留農薬のポジティブリスト制 度などにも触れ, 食品の安全に応用する実践力を育てること。 
鶴岡市の押井さんの農事暦が示されている. 5月中頃に田 植えをして, 除草剂をまく，8月に農薬散布を抢こなうとあ り，暦の隣にはミニヘリコプターによる散布の写真が添えら れている。

本文には，押井さんの話として，米作りは丈夫な苗を育て ることからはじまり，土づくりにも力を入れていると記し た後,「農薬についてもどうしても必要と考えられる場合に かぎり，与える時期や量に気をつけて使用しています」とあ り，効能は述べられているもののむしろネガティブな印象 を与えている。この後, 圃場整備や品種改良の説明があり, 「消費者が求める米作り」という節では，「できるだけ農薬や 化学肥料を使わない米を買うようにしている」という人の話 が出てくる．続きを引用すると「日本ではせまい農地で収穫 量を増やすために，これまでたくさんの農薬や化学肥料が使 われてきました，しかし農薬や化学肥料を使いすぎると，自 然や人体へのえいきょうが出ることが心配されています。最 近では，これらの使用をできるだけ減らし，たい肥などを 使った米作りもおこなわれています．押井さんたちも，ふつ うのさいばい方法と比べて, 農薬や化学肥料の使用を半分 以下にした米作りをしているそうだよ」.さらにこの隣にア イガモ農法の写真と「アイガモは雑草や害虫を食べるので農 薬がいらず，さらにアイガモのふんがそのまま肥料になるの で，化学肥料の量を減らすことができます」との説明が添え られている.

小学生はこのような形で, はじめて農薬のことを学ぶので ある. 思わず溜息が出てしまう.

\section{2. 高校 化学}

指導要領から見ると農薬のことが触れられていてもよいは ずだが，文系向け「化学基礎」(平成 25 年 $)^{4)}$ の「化学と人 間生活」の章で取り上げられているのは，金属，プラスチッ ク, セラミックス, セッケン, 食品添加物である. なお食品 添加物の項には言わずもがなの「食品添加物の中には, 多量 に摄取すると健康を害する可能性のあるものもあり, 使用量 が制限されたり，使用が禁止されたりしている」という説明 がある（多量に摂取しても健康を害さないものがあれば教え てほしいものだ)。一方，理系向け「化学」(平成25年) $)^{5)}$ は「有機化合物と人間生活」と題する章に「医薬品や洗剤と 人間生活」という節が設けられている。ここで紹介されるの はアスピリン，サリチル酸メチル，ペニシリンなどの医薬品 や合成洗剂, 染料である。農薬は人間生活に利用されている 有機化合物の代表的なものではないようだ.

\section{3. 高校 家庭科}

一般の高校生が履修する「家庭基礎」(平成 28 年度 $)^{6)}$ の 「これからの食生活を考える」という章で，日本の食料自給 率が低く，輸入食品に大きく依存していることが述べられた
後,「食の安全と環境への配慮」という節で，「危険な物質を 排除した安全な食べものを得ることで安心した食生活を送る ことができる. 安全な物を食べたいという消費者の要求に対 し, 農薬や化学肥料などの化学物質に頼らないで, 自然界の 力で生産された食品の生産が増えてきた」と書かれている. 農薬は食の安全を脅かす物として位置づけられている。

\section{4. 高校 農業と環境}

一般にはあまり馴染みのないが農業科の科目ではあるが, 教科書 $(\text { 平成 } 25 \text { 年度 })^{7)}$ 中でどのように農薬が报われている のかも見ておこう。第3章「栽培と飼育の基礎」の中に「作 物をとりまく環境とその管理」として，作物に被害を与える 生物と, 作物保護に関する説明がある. 当然, 殺虫, 殺菌, 除草剤の使用について言及があるが，いずれの場合もそれら をうまく使いましょうというょりは，できるだけ使わない方 がよいのだが，というニュアンスが感じられる。例えば「害 虫からの作物の保護」の項では, まず抵抗性品種を選び, 次 に栽培方法の工夫（害虫の発生しやすい時期を避ける，天 敵を利用する，対抗植物との輪作）による防除をおこなっ て，「大きな被害の広がりが予想される場合は薬剤を使用す る」と説明される。 また「薬剂の効果は大きいが, 人間や家 畜, 天敵, 他の生物などにも影響を与えることがあるので （中略）十分留意しなければならない」という注意が付け加 えられている。殺菌剤, 除草剤の使用についても, 薬剤を用 いるのは病気が拡大しそうであると判断したときや，雑草の 繁茂がはげしいときであり，䂆防的な使用には触れられてい ない．農業に関する実践的な能力を育てる科目の内容として は適正を欠くと言わざるを得ない.

\section{4. 学校教育と農薬}

小中高を通して「総合的な学習の時間」が設けられ，「横 断的・総合的な学習や探求的な学習」がおこなわれている. ここで環境問題や遺伝子組換え作物が対象として取り上げら れると, 農薬のことを学ぶ機会があると思われるが, 実態と してはよくわからない.

大学では, 当然, 農学系学部で農薬のことを解説する講義 が開講されている. 主な学生向けの教科書はいずれもやや古 くなってきた ${ }^{8)}$.

表向きの科目名に「農薬」は見えないが, 昆虫学, 植物病 理，食品衛生などの科目の中で取り上げられることも多い. 筆者自身が担当している科目名も「生物有機化学」で, その 中で代表的な農薬の化学と生化学を解説している. また合成 農薬には弊害が多いのでより環境にやさしい作物保護法を考 えよう，という文脈で構成される講義や授業も少なくない。 実際, 農薬は作物保護のツールとしてその有用性がかなり確 立されたものなので, 農薬に代わる防除法の探索は新しいも のにチャレンジする研究のひとつの方向として当然あってょ 
い.しかしそのような研究のキーワードは「無農薬」や「減 農薬」になり, さきの文脈は研究費の申請書などで研究の意 義をPRするために多用されることとなる．またその研究室 に所属して論文の指導を受ける学生は, 自らの研究の意義を 同じ文脈で説明することを求められるょうになる．結果とし て農学系といえども「農薬は悪いもの」という考えを持つ学 生は多い.

農学系以外では，環境科学，生態学，食品・食料に関する 社会科学などいわゆる教養科目の中でしばしば題材として取 り上げられる. 受講した学生は環境污染や遺伝子組換えと の関連でいくつかの具体的な化合物の名前（例えばラウン ドアップ）を知ることになるが，多くの場合，担当教員は農 薬に対してネガティブなイメージを持っており，学生にはそ のイメージが伝わる。また，英語購読の教材としてレイチェ ル・カーソンの「沈黙の春」が使用されることもあり，それ でDDTのことを知ったという学生もいた.

\section{5. 社会人・一般を対象とした農薬に関する教育}

社会人・一般を対象とする教育活動には，農薬工業会が精 力的に取り組んでいる。これについては別稿で述べられるの で紹介を省く。また平成 27 年には消費者庁が食品に関する リスクコミュニケーションの一環として，「知ろう，考えよ う，農薬のこと」を一般市民を対象に開催した ${ }^{9)}$.

一般に市民向けの啓発・教育イベントでは，個々の薬剂の 名前はほとんど出てこず，「集合名詞としての農薬」の話に なっている．何らかの場面で特定の農薬のことが話題になっ たときに，前提となっている登録制度や安全性確保の考え方 と適切に結びつけて考えてくれるかどうか，やや心許ないと
ころはある。

\section{6. ウィキペディアと農薬}

今日，農薬のことを知りたいと考えた人がまず調べるのは インターネットである．近年ではとりわけウィキペディアへ の依存度が高まっており，筆者の周辺でも（筆者自身も！） 知らない言葉に出会うとすぐにスマホで検索, ウィキの解説 でとりあえず納得，という場面を頻繁に見る。

ではそのウィキペディアで農薬はどのように解説されてい るのだろう。

定義は「農薬とは, 農業の効率化, あるいは農作物の保存 に使用される薬剂の総称。殺菌剂（中略）等をいう。また， 農薬取締法の上では, 稲作で使うアイガモなどの生物も, 害 虫を駆除することから特定農薬として指定されている. 虫害 や病気の予防や対策, 除虫や除草の簡素化, 農作物の安定供 給・長期保存を目的として, 近代化された農業では大量に使 用されている，一方，ヒトに対して毒性を示す農薬も多く知 られており，使用できる物質は法律で制限されている」。 おむ称妥当だが，「大量に使用」という言葉遣いや，すべて の化学物質が多かれ少なかれ毒性を持つのにあえて最後の一 文を加えているところを見ると，否定的な視点に立って書 かれている印象を受ける。 その後の説明の構成も表 2 の目次 に示すとおりで，全体的にネガティブな雾囲気を漂わせてい る ${ }^{10)}$.

次に環境影響が取りざたされているネオニコチノイドを調 べてみよう ${ }^{11)}$. 冒頭の説明を引用する。「ネオニコチノイド は, クロロニコチニル系殺虫剤の総称.（中略）急性毒性は 低いとされているが，昆虫に選択的に毒性を発揮し，人など

表2. ウィキペディアに見る農薬に関連した項目の目次の比較

\begin{tabular}{|c|c|c|c|c|c|c|c|}
\hline \multicolumn{2}{|r|}{ 農薬 10) } & \multicolumn{2}{|r|}{ ネオニコチノイド $(\text { 日本語版 })^{11)}$} & \multicolumn{2}{|c|}{ Neonicotinoid (English) ${ }^{12)}$} & \multicolumn{2}{|r|}{ Imidacloprid (English) ${ }^{13)}$} \\
\hline 1 & 歴史 & 1 & 概要 & 1 & History & 1 & Authorized uses \\
\hline 1.1 & 近代農薬 & 2 & 生態系への影響 & 2 & Market & 2 & Application to trees \\
\hline 1.2 & DDT と殺虫剂 & 2.1 & ミツバチ大量死・失踪との関係 & 3 & Agricultural usage & 3 & Background \\
\hline 1.3 & 除草剤 & 2.2 & トンボ & 3.1 & Efficacy & 4 & Brand names \\
\hline 1.4 & 環境運動と農薬批判 & 3 & 各国の状況 & 3.2 & Seed coatings & 5 & Biochemistry \\
\hline 2 & 日本の状況 & 4 & 種類 & 4 & Regulation & 6 & Environmental fate \\
\hline 2.1 & 農薬取締法での定義 & 5 & 脚注 & 4.1 & United States & 7 & Toxicology \\
\hline 3 & 製剤方法による分類 & 6 & 参考文献 & 4.2 & Europe & 7.1 & Bees and other insects \\
\hline 4 & 生物農薬 & 7 & 関連項目 & 4.2 .1 & Economic impact & 7.2 & Birds \\
\hline 5 & 農薬の危険性と規制 & 8 & 外部リンク & 4.3 & Canada & 7.3 & Aquatic life \\
\hline 5.1 & 残留農薬 & & & 5 & Mode of action & 7.4 & Plant life \\
\hline 5.2 & 生態系への影響 & & & 5.1 & Basis of selectivity & 8 & Health impact \\
\hline 6 & 出典 & & & 6 & Chemical properties & 9 & Overdosage \\
\hline 7 & 注釈・出典 & & & 7 & Toxicity & 10 & See also \\
\hline 8 & 関連項目 & & & 7.1 & Bees & 11 & References \\
\hline \multirow[t]{2}{*}{9} & 外部リンク & & & 7.2 & Other wildlife & 12 & Sources \\
\hline & & & & 8 & References & 13 & External links \\
\hline \multicolumn{2}{|c|}{ （最終更新 2016.11.05） } & & （最終更新 2016.09.20） & \multicolumn{2}{|c|}{ （最終更新 2016.11.01） } & & （最終更新 2016.11.11） \\
\hline
\end{tabular}

\footnotetext{
*いずれも最終閲覧日2016年11月14日.
} 
哺乳類には低濃度で単独使用した場合には比較的毒性が低い とされているが，有機リン系農薬と併用した場合には頭痛や 湿疹, ADHD（注意欠陷多動性症候群）に似た症状が発生 する場合がある」. 複数の人間が編集に関わっていると見え， 文に混乱が見られるし，因果関係が証明されていない毒性に 関する記述は不適切だ（なお2017年1月20日の時点では改 訂により「急性毒性」以下の部分は削除されている).

さらに目次 (表 2) に示すように, 内容は生態系への影響 が大きな部分を占めている. 作用メカニズムは概要の部分 に説明があり，「ネオニコチノイドは（中略）「ニコチン性ア セチルコリン受容体（AChR）」に結合し，神経を興奮させ 続けることで昆虫を死に至らしめる．また，アセチルコリン は，昆虫のみならず，人でも神経伝達物質として自律神経 系，神経筋接合部，中枢神経系に扔いて作用していることか ら，ネオニコチノイド系農薬のヒトの脳への影響，とりわけ 胎児・小児など脆弱な発達中の脳への影響を懸念する意見も ある」と, 不安を㮼る.ネオニコチノイドとは何だろうと調 べにきた学生や一般人にこれで納得されるときわめて問題 だ。しかし現実には，そういうことがかなりの頻度で起こっ ているのだろう.

これを英語版 ${ }^{12)}$ と比較してみると，大きなちがいに驚く. 英文を抄訳すると「ネオニコチノイドは神経に作用する殺虫 性化合物で，ニコチンに似た性質をもつ．シェルおよびバイ エルによって開発が開始され，一連の類縁化合物の中でイミ ダクロプリドは世界で最も多く使われている殺虫剂である. 鳥類や哺乳動物に対する毒性は，有機りん剂やカーバメート 剂に比べて低い.1990年代後半から 環境影響が議論になっ ており, ミッバチのコロニー崩壊などとの関連から，一部の 国々である種のネオニコチノイドの使用が禁止されている」 と辞書の説明としては, 妥当だ. 作用機構については項目が 立っており, 日本語版に比べてはるかに丁寧で適切な説明が ある.さらに選択性のメカニズムも分子レベルに踏み込んで 解説されている.

代表的化合物であるイミダクロプリドについては日本語版 にまだ説明がないのに対し, 英語版の説明は表 2 の目次に示 すとおり充実している ${ }^{13)}$.

このように多くの人々が参照するであろうウィキペディア のネオニコチノイドやイミダクロプリドに関する説明には大 きな問題がある．他の化合物についても同様の可能性は大い に考えられる．ウィキペディアの編集には誰でも参加できる ので, 当学会でタスクフォースを編成し, 各項目を精査して 改訂作業に取り組んではどうだろうか. 今日のウィキペディ アの影響力の大きさを考えると農薬の正しい理解の向上に とってかなり効果的ではないかと思う.

\section{7. ま と め}

以上，今，日本で農薬がどう教えられているかを見てきた
が，「ほとんど教えられていない」というのが結論のようだ. 教えられる場合でも，一部の専門科目を除いて食品の安全性 や環境影響が強調され，農薬は「使うべきではないもの」(あ るいは効能は認めるが「使わないほうがよいもの」）として 扱われることが多い，その際の農薬は集合名詞であり概念で ある. 個別の化合物にそれぞれ作用や毒性に特徵があること まで知る機会はないと言ってょい。

また作物生産に果たしている役割や貢献を考えると, 農薬 もひとつの立派な科学技術の発展の成果だと言えるのだが, 化学の分野でも実際には無視に近い状況である. 結果とし て, 大部分の人々に農薬は単なる食品や環境の污染物として 認識されている.

それでは農薬のことをどう教えればいいのだろうか？

やはりまずは, 農薬を使わなければどうなるかをしっかり 実感してもらうことだろう。農薬の効能は, (1)農作物の減収 を防ぐ, (2)農作業の軽減, の2点に尽きる.これに関連する データとして, (1)は(社)日本植物防疫協会がまとめた「病害 虫と雑草による農産物の損失」 ${ }^{14)}$, (2) は水稲作業の労働時間 の推移（(財)日本植物成長調節剤研究会）があり, 農林水産 省 ${ }^{15)}$ や農薬工業会 ${ }^{16)}$ のHPをはじめ広く用いられている.

しかし逆に言えばこれだけしかなく，負の影響を危惧する データがたくさんあるのと対照的だ。またいずれも学術雑誌 に掲載されたものではなく, データとしては弱いのを否めな い. 今後もっと様々な角度から農薬の効能を示すデータを収 集, 整理する必要があるように思う。多く実施されている薬 剂の圑場試験の結果は, 個々の剂の効果のみならずもっと広 く農薬の効果をPRするために利用されてよい，農薬学会誌 には「技術資料」の区分があり，活用が望まれる。

次に重要なのが, 農薬登録の仕組みとリスク管理体制につ いてわかりやすく説明し, 納得してもらうことだろう. 現在 の農薬は完璧ではないかもしれないが, 安全性はチェックさ れ, 効果を発揮しながらも防除対象生物以外への影響は最小 になるように使用法が定められた上で実用に供されているこ とはぜひ理解されてほしいものだ．これをいかに効果的にお こなうかについて, 次稿で巣山弘介氏（島根大学）がご自身 のアプローチを交えて解説されている，筆者はそのアプロー チに大いに感銘を受け自分の講義にも取り入れているのでこ の議論はそちらに譲り, より正しい情報が多くの人に伝わる 仕組みが今後も整備されていくことを祈って稿を閉じる.

\section{引用文 献}

1) http://www.mext.go.jp/a_menu/shotou/new-cs/youryou/syo/sya. htm\#5gakunen

2) http://www.mext.go.jp/a_menu/shotou/new-cs/youryou/kou/kou. pdf

3）小学社会 5年上, 日本文教出版, pp. 48-69, 2015. 
4）井口洋夫, 木下 實: 化学基礎, 実教出版, pp. 6-15, 2013.

5）井口洋夫, 木下 實: 化学, 実教出版, pp. 299-302, 2013.

6）家庭基礎，実教出版，pp. 114-116, 2016.

7）農業と環境 第3章, 実教出版, 2013.

8a）山下恭平, 水谷純也, 藤田稔夫, 丸茂晋吾, 江藤守総, 高橋信 孝: 新版 農薬の科学, 文永堂出版, 1996.

8b) 佐藤仁彦, 宮本 徹：農薬学, 朝倉書店, 2003 .

8c) 桑野栄一, 首藤義博, 田村廣人: 農薬の科学—生物制御と植物保 護, 朝倉出版, 2004.

9) http://www.caa.go.jp/policies/policy/consumer_safety/food_ safety/risk_commu_agricultural_chemicals.html

10) https://ja.wikipedia.org/wiki/\%E8\%BE\%B2\%E8\%96\%AC

11) https://ja.wikipedia.org/wiki/\%E3\%83\%8D\%E3\%82\%AA\%E3 \%83\%8B\%E3\%82\%B3\%E3\%83\%81\%E3\%83\%8E\%E3\%82\%A $4 \% \mathrm{E} 3 \% 83 \% 89$
12) https://en.wikipedia.org/wiki/Neonicotinoid

13) https://en.wikipedia.org/wiki/Imidacloprid

14) http://www.jppa.or.jp/tecinfo/data/sonsitsu_2008.pdf

15) http://www.maff.go.jp/j/nouyaku/n_tisiki/tisiki.html

16) http://www.jcpa.or.jp/qa/a6_18.html

URL上の資料はいずれも2016年11月11日閲覧.

\section{略 歴}

宮川 恒（みやがわ ひさし）

生年月日：昭和 32 年 6 月 27 日

最終学歴：京都大学大学院農学研究科農芸化学専攻修士課程

研究テーマ：植物二次代謝成分の生合成・代謝

趣味：酒類賞味, 名曲鑑賞, 野球とラグビー観戦 